\title{
Some New Insights into the Effects of the EU-South Korea Free Trade Area: The Role of Non Tariff Barriers
}

\author{
Yvan Decreux \\ CEPII, Paris and ITC, Geneva \\ Chris Milner \\ University of Nottingham, GEP \\ Nicolas Péridy \\ Université du Sud Toulon-Var, LEAD
}

\begin{abstract}
The present study proposes an updated and extended quantitative assessment of the EU-South Korea FTA, through a new version of MIRAGE CGE model. Several distinctive contributions are offered. Firstly, the quantitative assessment takes into account non-tariff barriers (NTBS) as well as tariffs. Second, it considers trade liberalization of goods, services as well as FDI (establishment). A third contribution is that simulations of policy changes are closely aligned with the actual agreement for each industry and service category. Finally, this article relies on recent techniques for calculating the tariff equivalents of NTBs following Kee et al. (2009). The main findings show that the EU may increase trade performance in several industries (chemicals, machinery, other manufactured and food products) as well as in specific services to a lesser extent (business, insurance and transport services). On the other hand, Korea takes advantage of the agreement

\footnotetext{
*Corresponding address: Yvan Decreux; International Trade Centre, Rue de Montbrillant 54, 1202 Geneva; Phone: +41 22730 0202; E-mail: y.decreux@gmail.com/Chirs Milner : School of Economics, Sir Clive Granger Building, The University of Nottingham, University Park, Nottingham NG7 2RD; Phone: +44 (0)115 9515624; Fax: +44 (0)115 9514159; E-mail: chris.milner@nottingham.ac.uk/ Nicolas Peridy, Université du Sud Toulon-Var (France), LEAD, UFR Sciences Economiques et Gestion. Avenue de l'Universite, BP 20132, F-83957 La Garde Cedex. Phone : +33 494142 982. Email : nicolas.peridy@univ-tln.fr. 
for specific manufactured products (textiles, leather/clothing, cars and other transport equipment).

- JEL Classification: F15

- Keywords: Free Trade Area, EU, Korea, CGE Models

\section{Introduction}

Since the initiation of the "Global Europe", the European Union (EU) has launched a new generation of Free Trade Agreements (FTAs) as a means of extending the trade liberalization process in the WTO context. In this regard, the FTA between the EU and the Republic of Korea (denoted thereafter Korea) is the first agreement of this new type (European Commission, 2009a and 2009b). ${ }^{1}$

On the Korean side, regional trade policy has been recently intensified: in addition to the renewal of the FTA with Asian and Pacific partners (APTA), some new FTAs have been concluded with Chile, EFTA, Singapore as well as ASEAN, the USA and India (WTO, 2010). Other FTAs are under negotiation, especially with Japan, Canada, Mexico and the EU. These agreements, cover inter alias, goods, services and investment, as a means of reforming the Korean economy and raising competitiveness through further liberalization in key industries (WTO, 2009).

Since the initiation of the Doha round in 2001, multilateral negotiations have tended to stall. Consequently, the development of regional integration may be considered as a means to achieve additional trade liberalization, and thus to increase trade between the regional partners. Expected benefits include gains due to the removal of NTBs, terms of trade effects, gains related to greater imperfect competition, such as scale economies and product varieties as well as dynamic gains, brought by capital accumulation, FDI, productivity spillover effects and other efficiency effects.

The existing studies on these regional agreements generally highlight significant trade and welfare effects for the partners involved. For example, the EU-Korea FTA was first assessed by Kim (2005), followed by Ko (2006) as well as Copenhagen Economics (2007). In particular, the Copenhagen study shows that the EU may significantly increase its exports of services to Korea. On the other hand,

${ }^{1}$ The other agreements under negotiation involve India, Singapore and Canada. In addition, a EU-Vietnam FTA is currently in scoping phase. 
Korea is expected to increase its exports of goods, especially motor vehicles and electronic machinery. This study also stresses significant production effects for goods and services, as well as positive GDP growth effects for Korea estimated to be about $1.6 \%$.

The present study proposes an updated and extended quantitative assessment of the EU-Korea FTA. It offers several distinctive contributions. Firstly, the quantitative assessment takes into account non tariff barriers (NTBs), which are disregarded in previous studies. It is expected that considering NTBs can change the quantitative assessment of the UE-Korea FTA to a large extent, since protection due to NTBs is generally greater than protection due to tariffs. Second, it considers trade liberalization of goods, services as well as FDI (establishment). A third contribution is that simulations represent closely the actual contents of the agreement. For example, the simulations concerning the tariff removal rigorously respect the official schedule described in the agreement (at HS6 level). In addition, the scenarios consider that NTB reductions are industry-specific and also closely related to the official agreement. The same remark also applies to services for which the precise schedule for each service category is introduced in the model.

A fourth contribution relates to the calculations of ad-valorem equivalents (AVEs) of NTBs. In this regard, we used as much as possible the observed information about trade costs (both qualitative and quantitative) to build up the calculations of AVEs. As a result, the computation technique does not rely on the residuals of gravity estimates, but on the appropriate transformation of actual trade effects of NTBs into tariff-equivalents (AVEs).

In addition, the CGE model is based on the new version of MIRAGE, developed by CEPII and updated in Decreux and Valin (2007). This new version includes characteristics of imperfect competition that have been introduced since this reference publication was published. These involve the consideration of both horizontal and vertical product differentiation for intra-industry trade, the specific modeling of trade costs and their components, the inclusion of FDI as well as improvements in the modeling of dynamics.

These contributions are intended to provide some new and more precise insights into the potential effects of the EU-Korea FTA. In particular, it will be shown that the results are different from the other studies especially with regard to trade impact for goods and services liberalization at sectoral level, mainly because of the consideration of NTBs.

This article is organized as follows: section II presents an overview of the EU- 
Korean FTA concerning goods and services (including Mode 3). Section III is dedicated to the measurement of trade restrictions in goods and services. In section IV, the new version of the MIRAGE model is implemented to calculate the effects of the EU-Korea FTA. The conclusions of the paper are set out in section V.

\section{An Overview of the EU-Korea FTA}

\section{A. Trade provisions for goods: customs duties, NTBs and others}

The schedule concerning the removal of customs duties is spread over a maximum of 20 years starting at the time the agreement enters into force. More precisely, goods are classified into 20 categories, each corresponding basically to annual stages for trade liberalization. Overall, the EU removes its customs duties for almost $80 \%$ of total imports from Korea at the time the agreement enters into force. Similarly, Korea immediately eliminates its tariffs for about two thirds of its imports originating from the EU (see Figure 1). Moreover, it is expected that almost all tariffs on industrial goods are phased out within 5 years. By year 7, both sides are expected to have achieved $98 \%$ duty elimination in terms of tariff lines. A limited number of highly sensitive agricultural and fishery products will have a

Figure 1. Tariff schedule of the EU-Korea agreement (\% of total imports fully liberalized)

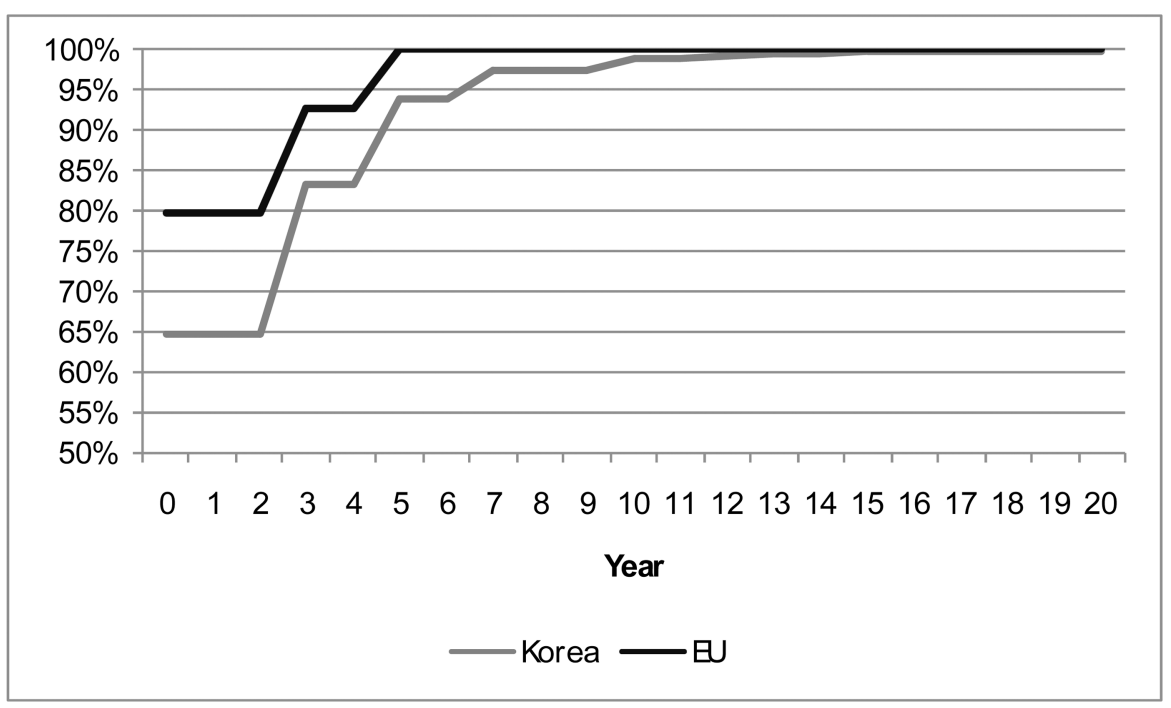

Source: own calculations from data in European Commission (2009a) 
transitional period beyond 7 years. Rice is excluded from the agreement as well as a few other agricultural products.

Table 1 summarizes the EU tariff liberalization schedule for the top-20 products imported from Korea. It can be observed that the highest base rates concern monitors and projectors $(12.3 \%)$, motor cars $(10 \%)$ as well as pneumatics $(4.5 \%)$. For these products, tariff removal is expected within 5 years at the latest. The other key products, essentially mechanical and electrical machinery as well as ships, face zero or very small tariffs which are expected to be removed at the time the agreement enters into force.

On the Korean side, tariff liberalization also covers almost all EU imports (see Table 2). Even for agricultural products, this agreement will eventually liberalize almost all imports, compared to only $2 \%$ before its implementation. However, the tariff schedule can take up to 20 years for some fruit (apple, pears) with safeguard clauses; up to 18 years for some oil seeds and oleaginous, green tea, sesame oil; up to 15 years for some vegetables, meat, products of animal origin or the milling

Table 1. Average EU tariff on the main import products originating from Korea (\%)

\begin{tabular}{clcc}
\hline $\begin{array}{c}\text { Import } \\
\text { rank }\end{array}$ & \multicolumn{1}{c}{ Designation } & Base rate & $\begin{array}{c}\text { Staging } \\
\text { category }\end{array}$ \\
\hline 1 & Television, sound recording, camera & $0.0 \%$ & 0 \\
2 & Parts suitable for television, radio, radars ... & $2.3 \%$ & 0 \\
3 & Other vehicles (1500 < cylinder $<2500 \mathrm{~cm} 3)$ & $10.0 \%$ & 3 \\
4 & Other vessels & $1.1 \%$ & 0 \\
5 & Tankers & $0.9 \%$ & 0 \\
6 & Monitors ans projectors & $12.3 \%$ & 5 \\
7 & Electronic integrated circuits & $0.0 \%$ & 0 \\
8 & Motor car (1500 < cylinder $<3000 \mathrm{~cm} 3)$ & $10.0 \%$ & 3 \\
9 & Part of data processing machines & $0.0 \%$ & 0 \\
10 & Motor car (1000 <ylinder $<1500 \mathrm{~cm} 3)$ & $10.0 \%$ & 5 \\
11 & Other devices, appliances and instruments & $1.6 \%$ & 0 \\
12 & Machinery with 360 degrees Revolving & $0.0 \%$ & 0 \\
13 & Data processing machines (other) & $0.0 \%$ & 0 \\
14 & Pneumatics used on motor cars & $4.5 \%$ & 3 \\
15 & Electronic integrated circuits & $0.0 \%$ & 0 \\
16 & Other vehicles (cylinder $>2500$ cm3) & $10.0 \%$ & 3 \\
17 & Parts and accessories of the motor vehicles & $3.5 \%$ & 0 \\
18 & Motor car (cylinder $<1000$ cm3) & $10.0 \%$ & 5 \\
19 & Data processing machines (other) & $0.0 \%$ & 0 \\
20 & Discs, tapes, solid-state non-volatile storage devi & $3.5 \%$ & 0 \\
\hline
\end{tabular}

Source: own computation from European Commission (2009a) 
Table 2. Average Korean tariff on the main import products originating from the EU (\%)

\begin{tabular}{clcc}
\hline $\begin{array}{c}\text { Import } \\
\text { rank }\end{array}$ & \multicolumn{1}{c}{ Designation } & Base rate & $\begin{array}{c}\text { Staging } \\
\text { category }\end{array}$ \\
\hline 1 & Air-coolers, Air Purifiers of Other Machines and M & $5.7 \%$ & 7 \\
2 & Electronic integrated circuits & $0.0 \%$ & 0 \\
3 & Medicaments & $7.8 \%$ & 3 \\
4 & Motor car $\left(\right.$ Cylinder $\left.>3000 \mathrm{~cm}^{3}\right)$ & $8.0 \%$ & 5 \\
5 & Motor car $(1500<$ cylinder $<3000 \mathrm{~cm} 3)$ & $8.0 \%$ & 3 \\
6 & Ferrous waste and scrap & $0.0 \%$ & 0 \\
7 & Part of combustion piston engines & $7.6 \%$ & 3 \\
8 & Pork (Meat) & $27.4 \%$ & 10 \\
9 & Parts and accessories of the motor vehicles & $8.0 \%$ & 0 \\
10 & Valves, taps, cocks and traps & $8.0 \%$ & 7 \\
11 & Other chemical products & $6.5 \%$ & 3 \\
12 & Turbo-compressors & $8.0 \%$ & 3 \\
13 & Aeroplanes & $0.0 \%$ & 0 \\
14 & Whisky & $20.0 \%$ & 5 \\
15 & Uranium enriched & $0.0 \%$ & 0 \\
16 & Gear boxes and parts thereof & $8.0 \%$ & 0 \\
17 & Switch boards & $8.0 \%$ & 0 \\
18 & Measuring or checking instruments & $7.3 \%$ & 0 \\
19 & Internal combustion engines & $5.9 \%$ & 3 \\
20 & Cobalt oxides & $5.5 \%$ & 0 \\
21 & Semi-finished products of iron or stee & $10.0 \%$ & 0 \\
22 & Parts of compressors & $8.0 \%$ & 0 \\
23 & Beauty or make-up preparations & $8.0 \%$ & 5 \\
24 & Electronic integrated circuits & $0.0 \%$ & 0 \\
25 & Pumps for piston engines & $8.0 \%$ & 5 \\
\hline
\end{tabular}

Source: own computation based on European Commission (2009a)

industry, preparation of vegetables, beverages; up to 10 years for some dairy products, live trees and other plants, cereals and sugar. In addition, some agricultural products are excluded from the agreement, like rice and rice products, whereas tariff rates are expected to remain unchanged for specific products (some fish products, pepper, barley, soya beans, onion, Korean citrus fruit, garlic, etc...). Finally, special schedule or special treatment for the removal of tariff rate quotas are granted to some fish products, grapes, dairy products, honey, oranges, malt, etc..

With regards to NTBs, the agreement includes the fundamental WTO rules, such as national treatment, prohibition of import and export restrictions, disciplines on state trading, etc. (European Commission, 2009b). In addition, the EU-Korea FTA 
includes specific disciplines on NTBs for four sectors: consumer electronics, motor vehicles, pharmaceutical products and medical devices as well as chemicals. Concerning consumer electronics, the agreement stresses the need for international standardization and simplification of certification as a means of reducing trade costs. Motor vehicle NTBs are also expected to be reduced, notably because the FTA provides for a wide-ranging recognition of international standards by Korea. For pharmaceuticals, the FTA addresses the need to strengthen the transparency in pricing decision. Finally, the FTA will introduce more transparency in laws, regulations and their implementation in the chemicals sector.

A specific chapter is introduced to tackle the problem of technical barriers to trade (TBTs), as a means of reinforcing cooperation on standards and regulatory issues (transparency in making rules, the use of international standards, etc.). Similarly, a chapter on Sanitary and Phytosanitary (SPS) measures is included in the FTA as a means of facilitating trade in animals and animal products, plants and plant products while maintaining a high level of human, animal and plant health. Finally, trade facilitation provisions are incorporated into the FTA (customs cooperation, simplification of border procedures, etc.) For that purpose, a customs committee has been established (European Commission, 2009b). ${ }^{2}$

\section{B. Trade provisions for services, including Mode 3}

A crucial aspect of the EU-Korea FTA is the liberalization of trade in services. The agreement generally goes beyond WTO commitments, especially by Korea. ${ }^{3}$ It includes specific provisions for telecommunications (removal of foreign ownership requirements in Korea, direct operation of EU satellite broadcasters into Korea, etc.), environmental services (cooperation on non-industrial waste waters) shipping (full market access and non discriminatory treatment in the use of port services and infrastructure in Korea), financial services (improvement of market access), express delivery services, air transport services (improved market access for EU services into Korea, etc). EU law firms are also to be allowed to open offices in Korea to advise foreign investors or Korean customers on non-Korean law

\footnotetext{
${ }^{2}$ It should be noted that the FTA does not alter duty drawback (DDB) provisions on EU-Korea trade. Duty drawback on duties paid on imported intermediates or raw materials is already allowed on trade between the EU and Korea. Although Korean DDB is of apparently minor significance in trade with the EU (European Commission, 2010), a prohibition of DDB would tend to lower the trade-enhancing effects of tariff and non-tariff liberalization associated with the FTA.

${ }^{3}$ Consult the WTO Database table on commitments, available at: http://tsdb.wto.org/simplesearch.aspx. Refer also to European Commission (2009b), p.7.
} 
(European Commission, 2009b). However, Korea already applies a more liberal regime vis-a-vis the EU than expected from GATS commitments. Still, some services sectors are excluded from the FTA. With regard to mode 1, these mainly concern audio-visual services, national maritime cabotage as well as some aircraft services on the EU side (repair and maintenance, selling and marketing of air transport services, handling services, rental services, etc.).

The services which are fully liberalized or which show few restrictions in the agreement generally involve business services, such as computer and related services, $\mathrm{R} \& \mathrm{D}$ (except restriction for services in natural sciences), telecommunication (equipment rental, etc.), advertising, market research and consulting, packaging, printing and convention services, as well as -for Korea only- technical testing and translation services. Communication services also show a high liberalization level (postal and telecom services), as well as construction services and environmental services (except mode 3).

On the other hand, some service sectors still remain relatively protected, despite some improvement in market access. These are: some professional services (legal accounting, auditing services), distribution services, education, health and social services, tourism and travel, recreational, cultural and sporting activities as well as transport (except a favorable market access for the EU concerning shipping and aircraft services into Korea) and energy services (for additional details, refer to Annexes 7-A-1 to 7-A-4 of the agreement).

Financial services also remain protected, despite some liberalization for specific activities. For Mode 1, these activities concern insurance services for maritime shipping and goods in international transit ${ }^{4}$ as well as specific banking services, such as transfer of financial information and data processing.

With regard to Mode 3, there is a medium level of liberalization of insurance services, with still some restrictions in terms of authorization, registration, etc... Banking services remain protected in Korea, especially with regard to credit unions, mutual saving banks, specialized capital finance companies, etc... despite an improvement in market access for the other banking services. Banking establishment into the EU is also restricted to a certain extent in a large number of Member States. ${ }^{5}$

\footnotetext{
${ }^{4}$ In Korea, reinsurance and insurance intermediation are also liberalized.

${ }^{5}$ The other provisions of the agreement cover free capital movement (Chapter 8), government procurement (chapter 9), intellectual property (Chapter 10), competition and transparency (chapters 11 and 12), dispute settlement (chapter 14) as well as specific provisions concerning sustainable development (chapter 13). In addition, specific protocols cover the problems of rules of origin, especially in the car sector, mutual administrative assistance in customs matters as well as cultural cooperation.
} 


\section{Estimating EU-Korea Trade Costs for Goods, Services and Establishment}

Basically, the methodology selected for calculating AVEs in goods primarily relies on Kee et al. (2009) (sometimes referred to as KNO methodology). This study is carried out in two stages. The first includes an estimation of the quantity impact of NTBs on imports. Then, this impact is transformed into price effects, using import demand elasticities calculated in Kee et al. (2008).

Since calculated AVEs are not available for all countries, the KNO methodology has been supplemented by a border-effect gravity approach, such as that presented in Fontagné et al. (2005). The starting point is the estimation of a gravity equation with border effects, which measure the specific cost of crossing a frontier, as a measure of market access. This methodology is close to that developed by Anderson and van Wincoop (2004). The key point is the precise definition of the trade cost function, which includes distance, tariffs, NTBs, as well as import prices (multilateral trade resistance). In the final estimation, the trade cost equation makes it possible to isolate each component (distance, prices and tariffs) whereas dummy variables for the border effect capture the influence of NTBs (as well as the home bias preference). The calculation of the border effects coefficient by sector and country makes it possible to derive the tariff equivalent, as:

$$
A V E=e^{\frac{\gamma}{\sigma}}-1
$$

where $\gamma$ and $\sigma$ correspond respectively to the estimated parameter for border effects and the Armington CES (constant elasticity of substitution).

Although this method differs from Kee et. al (2009), it proved to provide similar magnitudes of AVEs. The two approaches can thus be reconciled in the present study. For that purpose, the KNO figures are first used when available. The border effect approach is simultaneously implemented for these figures. This makes it possible to derive a scale which can be applied to both methods for achieving similar figures. Then, this scale, very close to unity, is applied to the border effect approach for the figures which are not available in the KNO approach. In other words, our results include the KNO figures supplemented by the border effect method, after having applied the appropriate scaling method.

Concerning the measurement of restrictions for Mode 1 services, the methodology selected for this study is based on Fontagné et al. (2009) following 
the initial development in Park (2002). Basically, it relies on the estimation of the fixed effects coefficient in gravity models. The advantage of this method is not to depend on the residuals of the model, which are likely to capture unobserved effects having nothing to do with protection. This method is also preferred to that based on import demand macroeconomic functions, which often show instability in long run parameter estimates and which do not correctly explain recent changes in imports. In addition, the standard macroeconomic import determinants barely fit the exchange of services. ${ }^{6}$

With regard to Mode 3, we suggest starting from a novel methodology initially developed by Fontagné and Mitaritonna (2009). It starts with qualitative information on the restrictions applied by each country in each service. In the next step, a multivariate statistical approach is used to transform this qualitative data into a trade restrictiveness synthetic index (TRI). Once TRIs are calculated, the method consists in transforming them into tariff equivalents. For that purpose, the TRIs are first regressed on the price-cost margin for each firm of each service sector in each country. The corresponding parameter estimate $(\beta)$ can then be used to calculate AVEs as follows:

$$
A V E \equiv 100\left(e^{\beta^{*} T R I}-1\right)
$$

Since this methodology provides TRIs and tariff equivalents for a limited number of countries and sectors, it has been extended for the missing countries. In addition, it has also been complemented by a very similar study (Findley and Warren, 2000) which provides TRIs for a wider range of services, especially within the business service category. Since the values of the TRIs calculated in Findley and Warren (2000) are close to those obtained in Fontagné and Mitaritonna (2009) for the common sectors and countries concerned, they have been used in the business sector as a complement of our results.

Table 3 records the estimated AVEs for the EU imports originating from Korea and for Korean imports originating from the EU. These AVEs have been calculated for the year 2004, following the GTAP7 aggregation scheme. Several features emerge from this table. First, the agriculture and food sector shows much higher AVEs in the EU than in Korea. This is because Korean protection essentially relies

${ }^{6}$ For additional discussion, see for example Blot and Cochard (2008). 
on ad-valorem tariffs. As a result, the average tariff protection is much higher in Korea but NTBs are lower.

On the other hand, the majority of manufactured industries show much higher protection from NTBs in Korea than in the EU, especially textile, leather-clothing, metals, machinery and above all cars and trucks as well as other transport equipment. This is mainly due to Korean standards and certification processes. ${ }^{7}$ In particular, Korean standards in the automotive industry are very specific, often non-transparent and subject to revisions. As a result, certification procedures are particularly long and costly. The other NTBs in the car industry mainly include numerous taxes (other than tariffs) and anti-imports sentiments in the local population. ${ }^{8}$ The remaining industries, i.e. chemicals and electronics generally show high and similar AVEs in both the EU and Korea.

For agricultural products, the progressive removal of customs duties in Korea with the FTA will correspond to a key improvement for EU exporters for accessing the Korea market. However, tariff removal in manufactured products will not significantly improve the EU market access into Korea, given the very high level of NTBs in sensitive sectors, especially in the car industry. Therefore, for these products, the reduction of NTBs becomes the key issue in the implementation of this agreement.

With regard to Mode 1, it is striking to observe that there is a significant gap between protection in Korea (for services originating from the EU) and protection in the EU (for Korean services). As a matter of fact, AVEs amount to $78 \%$ for "Other services in $\mathrm{Korea}^{9}$ ( $28 \%$ in the EU). In the same way, it represents $67 \%$ for insurance and $52 \%$ for finance ( $33 \%$ and $16 \%$ only in the EU, respectively). A significant gap is also recorded for trade (39\% instead of $19 \%)$.

This gap can be explained for example by special registration practices which are not opened to foreigners (construction), costly standards, "black list on public projects $^{10}$ as well as specific constraints in banking and financial services (non

${ }^{7}$ Standard and certification processes in the EU can also explain the significant AVEs found in textiles, although some other explanation may be found for example in rules of origin.

${ }^{8}$ The undervaluation of the Korean currency, especially with regard to the euro, is also often cited in the literature although it cannot be strictly considered as an NTB.

${ }^{9}$ These mainly involve energy (electricity, gas) as well as construction.

${ }^{10}$ This concerns in particular construction and engineering for which public projects require import substitution for all items that can be manufactured in Korea. Consequently, foreign items cannot be promoted (CEPS, 2007, p.63). 
Table 3. Estimated AVEs coefficients for NTBs applying to trade in goods and services

\begin{tabular}{|c|c|c|c|c|c|c|c|c|}
\hline GOODS & $\mathbf{E U}$ & Korea & MODE 1 & $\mathbf{E U}$ & Korea & MODE 3 & $\mathbf{E U}$ & Korea \\
\hline OthAgr & 0.101 & 0.053 & Other services & 0.278 & 0.779 & Trade & 0.192 & 0.394 \\
\hline Animal & 0.184 & 0.067 & Trade & 0.188 & 0.387 & $\begin{array}{l}\text { Commu- } \\
\text { nication }\end{array}$ & 0.215 & 1.012 \\
\hline Dairy & 0.322 & 0.057 & OthTransp & 0.155 & 0.106 & Finance & 0.030 & 0.517 \\
\hline Primary & 0.260 & 0.167 & SeaTransp & 0.228 & 0.187 & Insurance & 0.057 & 0.285 \\
\hline Food & 0.250 & 0.106 & AirTransp & 0.127 & 0.106 & Business & 0.289 & 0.278 \\
\hline BevTob & 0.185 & 0.068 & Communication & 0.195 & 0.235 & & & \\
\hline Textile & 0.191 & 0.507 & Finance & 0.161 & 0.525 & & & \\
\hline LeathCloth & 0.172 & 0.335 & Insurance & 0.331 & 0.672 & & & \\
\hline OthManuf & 0.140 & 0.302 & Business & 0.179 & 0.205 & & & \\
\hline Chemicals & 0.426 & 0.333 & Public Serv & 0.270 & 0.289 & & & \\
\hline Metals & 0.039 & 0.376 & & & & & & \\
\hline CarsTrucks & 0.073 & 0.592 & & & & & & \\
\hline TransEquip & 0.120 & 0.335 & & & & & & \\
\hline Electronic & 0.264 & 0.285 & & & & & & \\
\hline Machinery & 0.008 & 0.236 & & & & & & \\
\hline
\end{tabular}

Source: own calculations (multiply by 100 to give percentage rates of protection)

recognition of the "global equity concept, restrictions of foreign bank operations on the local currency, etc.)

However, this gap is less significant for communication and business services. For communication, this is due to the liberalization of cross-border services carried out in Korea in the past few years. On the other hand, transport services are slightly less protected in Korea than in the EU. Finally, public services remain protected both in Korea and in the EU (AVEs greater than 25\%).

With regard to Mode 3, the gap is even more acute for communications (101\% in Korea against $21.5 \%$ in the EU). It is also very significant for finance and insurance, with small AVE values in the EU and significant values in Korea. Trade is also much more protected in Korea (39\%) than in the EU (19\%), whereas business services show similar protection in both countries.

Overall, these results suggest that the application of the EU-Korea FTA can be expected to provide significant gains, especially because of reductions in NTBs in goods and restrictions in services. 


\section{Simulation Results}

\section{A. Theoretical framework of the new version of MIRAGE}

The main characteristics and contributions of the new version of MIRAGE are the following (Decreux and Valin, 2007). Dynamics is modeled following a sequential set-up, where installed capital is assumed to be immobile, even across sectors. Consequently, capital reallocation only results from the combined effect of depreciation and investment. This assumption gives investment a crucial role in terms of capital stock adjustment. In addition, cross-border investment (FDI) is introduced explicitly in a novel way. Indeed, standard CGE models generally assume that FDI results from international capital flows due to capital mobility. A major drawback is that it induces implausibly high cross-border capital flows (as compared to observed flows). On the other hand, MIRAGE attempts to induce more plausible capital flows by linking empirical evidence to theoretical consistency. This can be achieved by modeling domestic and foreign investment in a single framework where saving allocation is a function of initial investment flows, the current capital stock, the sectoral rate of return to capital as well as the adjustment speed of capital (for more details, refer to Decreux and Valin, 2007, pp.15-16). ${ }^{11}$ Dynamics is also driven by the exogenous evolution of technical progress and supply of other factors (labor, either skilled or unskilled, land and natural resources).

Another interesting specificity is the consideration of vertical product differentiation through the introduction of two quality ranges. This has been implemented by adding a specific CES nesting level in the utility function. The quality ranges are defined on a geographical basis, in such a way that goods produced in a developing country are assumed to belong to a different quality range than those produced in developed countries. ${ }^{12}$

Trade policy modeling is also a key characteristic in MIRAGE. In this regard, trade barriers include ad-valorem tariffs, specific tariffs, tariff quotas and antidumping duties which can be calculated in tariff equivalents. Preferential

\footnotetext{
${ }^{11}$ The model does not take into account FDI spillover effects on productivity, although an increasing empirical literature shows the existence of such effects (Peridy and Uttama, 2010).

${ }^{12}$ The corresponding CES is assumed to be lower than the Armington one. This implies that goods which belong to the same quality range are more substitutable than those which belong to different quality ranges. This implies for example that goods from a developing country compete more directly with goods from any other developing country than with goods from any developed country.
} 
agreements are also taken into account in a quasi-exhaustive way. The information is generally available at HS6 level, but it can also be aggregated in several product categories. In addition, specific features of the agricultural sector are introduced. These include export subsidies, price support, production quotas, land allocation across crops as well as capital and land subsidies.

The other features and assumptions are standard. While labor is assumed to be perfectly mobile across sectors, land is distributed across sectors with a constant elasticity of transformation function. For each imperfectly competitive sector, the number of firms immediately adjusts to respect a zero-profit condition. On the demand side, final consumption is modeled in each region through a representative agent characterized with an intra-temporal utility function. A fixed share of the regional income is allocated to savings, the remaining share to consumption, with a first CES. The four-stage CES are modeled in order to consider the consumer choice within each sector, across countries, across varieties and across qualities (for additional information and the complete model setup, refer to Decreux and Valin, 2007).

\section{B. Scenarios and baselines}

Table 4 summarizes the baselines and scenarios which have been selected for the simulations. The main characteristic is that they as close as possible to the official schedule described in the EU-Korea agreement (section II). Basically, the baseline refers to the multilateral, regional, or service-specific agreements which are likely to affect the impact of the EU-Korea FTA. It includes two options. The first option assumes that the Doha round will not be concluded and therefore its contents not implemented. Similarly, it only considers the existing FTAs in force with the EU and Korea, assuming that the FTAs under negotiations will not be carried out. ${ }^{13}$ Finally, it also includes the possibility of a $50 \%$ increase in the estimated rate of Korean protection for services (subject to the limit of the GATS commitment). As explained previously, this assumption is due to the fact that the current regime in Korea is more liberal than its GATS commitments. This suggests a significant liberalization has already been achieved between Korea and its partners. Consequently, there is a possibility that Korea will increase its protection level up to the GATS commitments, except with regards to the partners which have

\footnotetext{
${ }^{13}$ FTA in force with Korea: ASEAN, Chile, EFTA, Singapore and India; FTA under negotiation with Korea: the USA and Canada (the FTA under negotiation with Japan and Mexico are disregarded given the delays in the negotiations). FTA under negotiation with the EU: India, Singapore and Canada.
} 
Table 4. Baseline and scenarios used for the EU-FTA simulations

\begin{tabular}{|c|c|c|}
\hline \multicolumn{3}{|c|}{ BASELINE: } \\
\hline & Baseline 1 & Baseline 2 \\
\hline & Doha: No agreement & Doha: standard liberalisation (1) \\
\hline & $\begin{array}{l}\text { FTAs: only those currently in } \\
\text { force }\end{array}$ & $\begin{array}{l}\text { FTAs: including also Korea- } \\
\text { USA, Korea-Canada,EU- }\end{array}$ \\
\hline & Services: increase in Korean & India, EU-Singapore, EU- \\
\hline & protection by $50 \%$ & Canada (2) \\
\hline & & $\begin{array}{c}\text { Services: increase in Korean pro- } \\
\text { tection by } 25 \%\end{array}$ \\
\hline \multicolumn{3}{|l|}{ SCENARIO: } \\
\hline TARIFFS & \multirow{2}{*}{\multicolumn{2}{|c|}{ Official schedule }} \\
\hline NTBs: & & \\
\hline - Automotive & \multicolumn{2}{|c|}{$\begin{array}{l}60 \% \text { cut at } \mathrm{t}=0 \text { (Korea, out of which } 10 \% \text { at MFN basis); } \\
\text { another } 20 \% \text { cut at } \mathrm{t}=5 \text { (Korea) }\end{array}$} \\
\hline - Consumer electronics & \multicolumn{2}{|c|}{$80 \%$ cut over 5 years (Korea) } \\
\hline - Pharmaceuticals & \multicolumn{2}{|c|}{$50 \%$ cut at $\mathrm{t}=0$ (Korea, MFN basis) } \\
\hline - Other industries & \multicolumn{2}{|c|}{$20 \%$ cut (EU and Korea) } \\
\hline \multicolumn{3}{|l|}{ SERVICES } \\
\hline - telecom and financial & \multicolumn{2}{|l|}{$10 \%$ cut at $\mathrm{t}=2$ (Korea) } \\
\hline - business services & \multicolumn{2}{|l|}{$10 \%$ cut at $\mathrm{t}=10($ Korea $)$} \\
\hline - Other services & \multicolumn{2}{|l|}{ current level of protection } \\
\hline TRADE FACILITATION & \multicolumn{2}{|l|}{ No } \\
\hline
\end{tabular}

(1) Including services and trade facilitation

(2) Korea-US: Tariff: $95 \%$ of liberalization in 3 years and the rest in 10 years. Around $2 \%$ is excluded (agriculture); Services: binding of actual openness (similar to EU but without additional liberalization in 3 sectors); Korea with Canada: 95\% cut for goods. FTAs with the EU (India, Singapore and Canada): same bilateral tariff cuts as for the EU-Korea agreement. The EU-Vietnam FTA under negotiation is excluded from this baseline as its timing and conclusion are still too uncertain. The same remark also applies to the Korea-Japan and Korea-Mexico FTAs.

implemented a FTA with Korea (especially the EU).

On the other hand, the second option expects the Doha Round to be concluded. Consequently, this option includes a standard multilateral liberalization, including services. In addition, it takes into account the FTAs under negotiation with Korea, which involve the USA and Canada. Similarly, it includes the FTAs under negotiation with the EU. Finally, it assumes a 25\% increase in the Korean service protection (using the GATS commitments as an upper bound).

With regard to the scenario selected here, it includes a unique option, which is as close as possible to the official content of the agreement. In particular, the scenario 
concerning the phasing out of tariffs respects rigorously the official schedule. It is spread over 20 years depending on the product considered. ${ }^{14}$ Turning to NTBs in goods, the scenario is also close to the provisions of the agreement, by distinguishing several industries. Concerning imports into Korea, the automotive industry is expected to enjoy a $60 \%$ cut in NTBs when the agreement is in force. This cut is assumed to be essentially applied on a bilateral basis (only $10 \%$ on MFN basis). In addition, a remaining $20 \%$ cut is also expected after 5 years. NTBs for consumer electronics are expected to be cut $80 \%$ over 5 years. Pharmaceuticals are assumed to have NTBs in Korea immediately reduced by $50 \%$ (on MFN basis). The other industries will be applied a $20 \%$ bilateral cut for both the EU and Korea.

Concerning services, the scenario is also based on the content of the agreement. As already said, the current regime in Korea is more liberal than its GATS commitments. Therefore, only a limited additional liberalization is assumed with the EU. Therefore, the EU-Korea FTA will give rise to a consolidation of this liberalization process, with no more cuts for most services, except telecommunications, financial services as well as business services which are expected to enjoy an additional $10 \%$ cut.

Finally, trade facilitation is considered in the sensitivity analysis. It is taken into account by considering that the time which is necessary to accomplish import is reduced (Decreux and Fontagné, 2009).

\section{Simulation results and comparison with alternative studies.}

The results presented below refer to the "central simulation based on the baselines and scenario described above. Simulations are implemented over 15 years (from 2010 to 2025) from GTAP7 database (base year 2004). Results are generally presented as the percentage change of a given variable in 2025 due to the EU-Korea FTA. General results on GDP and welfare are presented first. Then, the trade effects are discussed, including global and bilateral exports and imports as well as trade balances. Next, sectoral results are detailed. These include production and trade effects (including bilateral). Then, employment effects are discussed at sectoral level. In addition, other macroeconomic results are analyzed, including factor returns, exchange rates and tariff revenue. To conclude, a comparison with the other existing studies, especially the Copenhagen study (2007), is provided.

\footnotetext{
${ }^{14}$ The only simplification concerns the final year of tariff removal, expected 15 years after the agreement is in force. Since very few products are officially expected to be liberalized after 15 years (see section 1), the bias introduced by this simplification is insignificant.
} 
Table 5. GDP changes due to the EU-FTA FTA (\%).

\begin{tabular}{llcc}
\hline & & Baseline 1 & Baseline 2 \\
\hline r01 & European Union & $\mathbf{0 . 0 7}$ & $\mathbf{0 . 0 8}$ \\
r02 & Korea & $\mathbf{0 . 8 4}$ & $\mathbf{0 . 4 6}$ \\
r03 & Japan & $-0,07$ & -0.06 \\
r04 & USA & -0.03 & -0.03 \\
r05 & China \& Taiwan & -0.01 & -0.02 \\
r06 & ASEAN & -0.01 & -0.01 \\
r07 & India & -0.00 & -0.00 \\
r08 & Oceania & -0.05 & -0.04 \\
r09 & Canada & -0.05 & -0.04 \\
r10 & EFTA & 0.01 & 0.01 \\
r11 & Brazil & -0.01 & -0.01 \\
r12 & Chile & -0.01 & -0.01 \\
r13 & Russia & 0.00 & -0.00 \\
r14 & Rest of World & -0.01 & -0.01 \\
\hline
\end{tabular}

Table 5 unsurprisingly indicates that the GDP effect of the EU-Korea FTA is generally more significant for Korea (up to $0.84 \%$ GDP growth) than for the EU (less than $0.1 \%$ ). This result is not surprising because of the higher initial protection in Korea than in the EU, as well as the relatively higher importance of the EU in Korean trade than Korea in the EU trade.

It must also be observed that baseline 2 leads to reduced GDP effects for Korea but not for the EU. This is due to the fact that baseline 2 includes three components which may have opposite effects on GDP. The first includes Doha, which reduces the bilateral preference margin created by the EU-Korea FTA (negative effect). The second component relates to FTAs under negotiation, which have ambiguous effects. Although these FTAs also reduce the preference margin for EU and Korea, they can also improve efficiency effects, since overall discrimination is reduced. Finally, the last component involves a less significant rise in Korean service protection ( $25 \%$ instead of $50 \%$ ) which will not be implemented vis-à-vis the EU if the FTA is concluded. This provides a lower increase in the preference margin and leads to less GDP gains.

It is also worth mentioning that the other countries generally face GDP losses. These losses essentially result from trade diversion due to the implementation of the EU-Korea FTA. However, their magnitude is generally insignificant, except for Japan which is likely to lose more significant market shares with Korea.

Welfare gains are presented in Table 6 . These gains are made up of five 
components: factor accumulation (capital and land), allocation efficiency gains, specific gains due to trade cost reduction, variety gains as well as terms of trade gains. ${ }^{15}$ A last gain (called "other gains") corresponds to residuals which generally include additional allocation efficiency gains.

Korea unsurprisingly gains more than the EU (up to $1.12 \%$ for Korea compared to $0.02 \%$ for the EU). The higher welfare gains expected for Korea are essentially due to its initial higher level of protection as well as to its smaller economic size relative to the EU. For the same reasons as previously explained, welfare gains may be reduced in baseline 2 relative to baseline 1 due to the reduced preference margin when implementing the FTA (25\% instead of $50 \%)$ and possibly the extension of preferences to other partners, both multilaterally and regionally.

The global welfare gain for Korea is mainly due to terms of trade improvement, which results from the lower import prices due to NTB reductions. The other significant gains include capital accumulation (through increased investment) as well as variety gains (increase in the number of varieties available to the consumer due to the FTA). On the other hand, the EU gain is essentially explained by trade costs saved on the export side thanks to NTB reductions, whereas the EU experiences a slight deterioration of its terms of trade.

With regard to trade effects, both the EU and Korea show a positive effect on overall exports and imports. Concerning Korea, this effect leads to an overall increase of (up to) $5.5 \%$ of its overall exports and $5.9 \%$ of its imports. The rise in Korean trade is of course very significant with the EU (up to $38.4 \%$ ), as shown in

Table 6. Decomposition of the welfare gain (\%)

\begin{tabular}{lcccc}
\hline & & EuropeanUnion & Korea \\
\hline & Baseline 1 & Baseline 2 & Baseline 1 & Baseline 2 \\
\hline Allocation efficiency gains & 0.00 & -0.00 & 0.00 & 0.00 \\
Capital accumulation gains & 0.01 & 0.01 & 0.36 & 0.25 \\
Land supply gains & 0.00 & 0.00 & -0.00 & -0.00 \\
Other gains & -0.00 & -0.00 & 0.09 & 0.03 \\
Terms of trade gains & -0.02 & -0.01 & 0.54 & 0.39 \\
Trade cost gains & 0.03 & 0.03 & 0.04 & 0.04 \\
Variety gains & -0.01 & -0.00 & 0.10 & 0.04 \\
Welfare & 0.01 & 0.02 & 1.12 & 0.75 \\
\hline
\end{tabular}

\footnotetext{
${ }^{15}$ Terms of trade gains include the effects of the reduction in import prices due to NTB reductions. Trade cost gains include the reduction in production costs afforded by the reduction of NTBs, for a given export price.
} 
Table 7. Effects on bilateral exports and imports (no EU-intra trade)

\section{BILATERAL EXPORTS: EU}

\begin{tabular}{lcccc}
\hline & Baseline 1 & & Baseline 2 & \\
\cline { 2 - 5 } & $\%$ & billion euros & $\%$ & billion euros \\
\hline r02 Korea & $\mathbf{8 2 . 5 8}$ & $\mathbf{4 1 . 0 8}$ & $\mathbf{6 2 . 0 8}$ & $\mathbf{3 3 . 0 2}$ \\
r03 Japan & -0.43 & -0.35 & -0.46 & -0.40 \\
r04 USA & -0.34 & -1.72 & -0.37 & -1.90 \\
r05 China \& Taiwan & -0.16 & -0.39 & -0.29 & -0.72 \\
r06 ASEAN & -0.17 & -0.29 & -0.26 & -0.44 \\
r07 India & -0.20 & -0.19 & -0.20 & -0.40 \\
r08 Oceania & -0.36 & -0.22 & -0.38 & -0.24 \\
r09 Canada & -0.39 & -0.20 & -0.43 & -0.26 \\
r10 EFTA & -0.13 & -0.24 & -0.13 & -0.24 \\
r11 Brazil & -0.19 & -0.07 & -0.24 & -0.09 \\
r12 Chile & -0.25 & -0.03 & -0.23 & -0.03 \\
r13 Russia & -0.13 & -0.24 & -0.16 & -0.31 \\
r14 Rest of World & -0.25 & -2.04 & -0.29 & -2.37 \\
\hline
\end{tabular}

BILATERAL EXPORTS: KOREA

\begin{tabular}{lcccc}
\hline & Baseline 1 & \multicolumn{3}{c}{ Baseline 2} \\
\cline { 2 - 5 } & \multicolumn{1}{c}{$\%$} & billion euros & $\%$ & billion euros \\
\hline r01 European Union & $\mathbf{3 8 . 3 9}$ & $\mathbf{3 4 . 4 1}$ & $\mathbf{2 3 . 0 6}$ & $\mathbf{2 2 . 9 5}$ \\
r03 Japan & -1.84 & -0.61 & -0.93 & -0.31 \\
r04 USA & 2,99 & 2.57 & 2.63 & 2.50 \\
r05 China \& Taiwan & -1.57 & -3.29 & -0.53 & -1.09 \\
r06 ASEAN & -0.54 & -0.38 & 0.08 & 0.09 \\
r07 India & 0.14 & 0.03 & 0.82 & 0.11 \\
r08 Oceania & 0.49 & 0.05 & 1.18 & 0.14 \\
r09 Canada & 5.51 & 0.39 & 4.71 & 0.44 \\
r10 EFTA & 2.50 & 0.07 & 2.45 & 0.07 \\
r11 Brazil & -1.37 & -0.05 & -0.26 & -0.01 \\
r12 Chile & 4.56 & 0.08 & 3.01 & 0.05 \\
r13 Russia & 1.99 & 0.16 & 1.88 & 0.15 \\
r14 Rest of World & 1.68 & 1.31 & 2.10 & 1.67 \\
\hline
\end{tabular}

Table $7 .{ }^{16}$ Turning to the EU, export and import growth are respectively (up to) $1.4 \%$ and $1.3 \%$. EU bilateral trade with Korea increases very significantly (up to

${ }^{16}$ Korean export figures may be slightly inflated because the outsourcing of Korea production to Asian countries since the base year 2004 is not captured in the estimates. 
Table 8. Effects on bilateral exports and imports (billion euros)

\begin{tabular}{lcc}
\hline & Baseline 1 & Baseline 2 \\
\hline EU Exports to Korea & 41.08 & 33.02 \\
EU Imports from Korea & 34.41 & 22.95 \\
EU Trade balance with Korea & 6.68 & 10.08 \\
\hline
\end{tabular}

$82.6 \%$ ), as a result of the initial high protection in Korea. ${ }^{17}$

With regard to bilateral trade effects in value (Table 8), the increase in EU exports to Korea amounts to a minimum of 33 billion euros and a maximum of 41 billion euros depending on the baseline considered. This is more than the expected gain of 19 billion euros in the Copenhagen study. This difference is mainly due to the fact that the Copenhagen study disregards the trade effects of NTB reductions. For the same reason, EU imports from Korea increase by up to 34 billion euros. This makes it possible to improve the EU trade balance with regard to Korea by up to 10.1 billion euros. This improvement is significant, given that in 2008, the EU faced a 13.8 billion euros trade deficit vis-à-vis Korea.

Turning to the analysis at the industry level, the EU-Korea FTA generally has small production effects in the EU (Table 9). Small positive effects may be found in some animal and food products (meat, dairy products, beverage and tobacco and other food products), chemicals, machinery as well as other manufactured products. Transport services (sea and air transports) also exhibit a small production expansion in baseline 1. Conversely, a reduction in production occurs in textiles, leather and clothing as well as cars and other transport equipment. However, it has to be remembered that such a reduction is calculated as compared to the baseline. Consequently, considering observed growth trends in the EU, production may not be reduced in absolute terms as compared to today, but rather it will not expand as much as it would do without the agreement. This remark also applies to employment and other variables.

\footnotetext{
${ }^{17}$ There is some evidence of trade diversion on the EU side, since bilateral exports of the EU vis-a-vis third-countries is reduced (Table 7), especially with Japan. Similarly, the rise in EU imports from Korea is partly explained by the replacement of EU imports from third countries. The evidence of trade diversion is less stringent for Korea. As a matter of fact, Korean bilateral exports increase not only with the EU, but also with most of its partners. This can be explained by the rise in competitiveness and efficiency of the Korean economy due to the reduction of the initial significant protection (especially NTBs). This export rise is particularly significant with countries which already enjoy an FTA with Korea (USA, Chile, EFTA, etc...). In other words, the rise in Korean efficiency due to the implementation of the FTA with the EU also benefits Korea with regards to exports markets which have already implemented such an FTA.
} 
Table 9. Production effects: Sectoral breakdown

\begin{tabular}{|c|c|c|c|c|}
\hline & \multicolumn{2}{|c|}{ EUROPEAN UNION } & \multicolumn{2}{|c|}{ KOREA } \\
\hline & Baseline 1 & Baseline 2 & Baseline 1 & Baseline 2 \\
\hline a1 Agriculture and primary products & 0.05 & $\mathbf{0 . 0 3}$ & -0.45 & -0.07 \\
\hline s01 Meat \& Animal products & 0.89 & 0.54 & -7.89 & -3.94 \\
\hline s02 Dairy & 0.63 & 0.50 & 1.20 & -16.98 \\
\hline s03 Other Agriculture & 0.10 & 0.06 & -0.93 & -0.66 \\
\hline s04 Food & 0.15 & 0.12 & -2.85 & -2.21 \\
\hline s05 Beverage \& Tobacco & 0.13 & 0.13 & -0.38 & -0.54 \\
\hline s06 Primary & -0.01 & -0.01 & -0.09 & -0.07 \\
\hline a2 Manufactured products & -0.01 & 0.02 & 0.90 & 0.41 \\
\hline s07 Textile & -2.22 & -2.06 & 34.25 & 24.33 \\
\hline s08 Leather \& Clothing & -0.04 & -0.14 & 9.4 & 88.77 \\
\hline s09 Chemicals & 0.17 & 0.09 & -1.01 & -0.88 \\
\hline s10 Metals & 0.02 & 0.08 & -1.98 & -1.70 \\
\hline s11 Cars \& Trucks & -1.38 & -0.40 & 19.34 & 8.08 \\
\hline s12 Planes Ships Bikes Trains & -0.39 & -0.65 & 1.75 & 4.72 \\
\hline s13 Electronic equipment & 0.05 & 0.04 & -1.56 & -0.77 \\
\hline s14 Machinery & 0.27 & 0.19 & -2.94 & -1.96 \\
\hline s15 Other Manufactured products & 0.16 & 0.13 & -1.35 & -1.23 \\
\hline a3 Services & $\mathbf{0 . 0 0}$ & $-\mathbf{0 . 0 0}$ & -0.23 & -0.13 \\
\hline s16 Trade & -0.00 & 0.01 & 0.42 & 0.27 \\
\hline s17 Sea Transport & 0.69 & -0.07 & -2.75 & -0.07 \\
\hline s18 Air Transport & 0.12 & -0.07 & -1.58 & -0.09 \\
\hline s19 Other Transport & 0.03 & -0.00 & -0.12 & 0.02 \\
\hline s20 Communication & 0.00 & -0.01 & -0.08 & -0.03 \\
\hline s21 Finance & -0.01 & -0.01 & -0.07 & -0.06 \\
\hline s22 Insurance & 0.02 & -0.00 & -0.82 & -0.53 \\
\hline s23 Business services & 0.01 & 0.01 & -0.96 & -0.59 \\
\hline s24 Recreation \& related Services & -0.02 & -0.02 & 0.47 & 0.33 \\
\hline s25 Admin Defence Health Education & -0.01 & -0.01 & -0.05 & -0.04 \\
\hline s26 Other Services & 0.01 & 0.02 & 0.94 & 0.65 \\
\hline TOTAL (GDP change) & 0.07 & 0.08 & 0.84 & 0.46 \\
\hline
\end{tabular}

Korea shows to some extent a reverse picture, although the magnitude of the production effects is more significant. As a matter of fact, significant increases can be observed for textiles, cars/trucks, leather/clothing as well as other transport equipment to a lesser extent. The main reasons which underlie this result may be found not only in the high initial NTBs applied by Korea (especially for cars and 
Table 10. Trade effects: European Union (\% change, sectoral breakdown)

\begin{tabular}{|c|c|c|c|c|}
\hline & \multicolumn{2}{|c|}{ EXPORTS: EU } & \multicolumn{2}{|c|}{ IMPORTS: EU } \\
\hline & Baseline 1 & Baseline 2 & Baseline 1 & Baseline 2 \\
\hline a1 Agriculture and primary products & 1.87 & 1.15 & 0.62 & 0.49 \\
\hline s01 Meat \& Animal products & 12.33 & 6.06 & 0.72 & 0.59 \\
\hline s02 Dairy & 13.10 & 8.35 & 1.87 & 1.17 \\
\hline s03 Other Agriculture & 1.66 & 1.31 & 0.50 & 0.45 \\
\hline s04 Food & 2.71 & 2.12 & 0.61 & 0.48 \\
\hline s05 Beverage \& Tobacco & 1.07 & 0.97 & 0.22 & 0.22 \\
\hline s06 Primary & 0.01 & -0.02 & 0.20 & 0.14 \\
\hline a2 Manufactured products & 1.61 & 1.17 & 1.95 & 1.29 \\
\hline s07 Textile & -0.54 & -1.36 & 4.60 & 3.45 \\
\hline s08 Leather \& Clothing & 5.44 & 2.72 & 0.76 & 0.56 \\
\hline s09 Chemicals & 1.60 & 0.99 & 0.91 & 0.85 \\
\hline s10 Metals & 1.99 & 1.52 & 0.36 & 0.37 \\
\hline s11 Cars \& Trucks & 5.56 & 5.671 & 4,75 & 7.14 \\
\hline s12 Planes Ships Bikes Trains & 0.61 & -0.02 & 1.35 & 1.46 \\
\hline s13 Electronic equipment & 1.89 & 1.34 & 0.62 & 0.47 \\
\hline s14 Machinery & 1.94 & 1.33 & 0.61 & 0.62 \\
\hline s15 Other Manufactured products & 0.79 & 0.58 & 0.41 & 0.42 \\
\hline a3 Services & 0.27 & 0.00 & 0.18 & 0.23 \\
\hline s16 Trade & 0.74 & 0.24 & 0.16 & 0.21 \\
\hline s17 Sea Transport & 0.93 & -0.12 & 0.27 & 0.17 \\
\hline s18 Air Transport & 0.28 & -0.15 & 0.14 & 0.17 \\
\hline s19 Other Transport & 0.10 & -0.18 & 0.20 & 0.21 \\
\hline s20 Communication & 0.19 & -0.11 & 0.15 & 0.20 \\
\hline s21 Finance & 0.18 & -0.00 & 0.17 & 0.23 \\
\hline s22 Insurance & 0.27 & 0.06 & 0.22 & 0.25 \\
\hline s23 Business services & 0.41 & 0.14 & 0,15 & 0.21 \\
\hline s24 Recreation \& related Services & -0.18 & -0.22 & 0.22 & 0.27 \\
\hline s25 Admin Defence Health Education & 0.07 & -0.26 & 0.24 & 0.30 \\
\hline s26 Other Services & -0.08 & -0.15 & 0.23 & 0.26 \\
\hline TOTAL & 1.40 & 0.96 & 1.27 & 0.88 \\
\hline
\end{tabular}

truck $59 \%$, textiles $51 \%),{ }^{18}$ but also in the strong comparative advantage in these industries with regard to the EU. As a matter of fact, Korean exports of textiles to the EU are three times higher than the EU exports to Korea. This figure amounts to five times higher for transport equipment. Negative production effects are recorded

\footnotetext{
${ }^{18}$ NTB reductions from a high initial level lead to factor reallocation and increased efficiency which makes it possible to increase the production of the concerned industries.
} 
Table 11. Trade effects: Korea ( $\%$ change, sectoral breakdown)

\begin{tabular}{|c|c|c|c|c|}
\hline & \multicolumn{2}{|c|}{ EXPORTS: KOREA } & \multicolumn{2}{|c|}{ IMPORTS: KOREA } \\
\hline & Baseline 1 & Baseline 2 & Baseline 1 & Baseline 2 \\
\hline a1 Agriculture and primary products & 4.87 & $\mathbf{4 , 5 2}$ & 2,73 & 1.86 \\
\hline s01 Meat \& Animal products & 10.98 & 6.80 & 37.38 & 11.64 \\
\hline s02 Dairy & 65.81 & 46.91 & 223.00 & 138.33 \\
\hline s03 Other Agriculture & 2.59 & 1.80 & 2.47 & 2.33 \\
\hline s04 Food & 4.72 & 3.03 & 10.80 & 8.25 \\
\hline s05 Beverage \& Tobacco & 0.38 & 0.42 & 26.36 & 23.59 \\
\hline s06 Primary & 0.64 & 0.55 & -1.00 & -0.93 \\
\hline a2 Manufactured products & 6.04 & 4.16 & 7.92 & 5.91 \\
\hline s07 Textile & 42.87 & 27.67 & 13.30 & 9.53 \\
\hline s08 Leather \& Clothing & 70.88 & 37.11 & 5.12 & 2.28 \\
\hline s09 Chemicals & 5.40 & 4.80 & 8.85 & 6.02 \\
\hline s10 Metals & -2.95 & -2.12 & 4.90 & 3.30 \\
\hline s11 Cars \& Trucks & 51.41 & 23.84 & 94.86 & 82.41 \\
\hline s12 Planes Ships Bikes Trains & 2,96 & 6.14 & 6.19 & 3.89 \\
\hline s13 Electronic equipment & -0.92 & -0.38 & 1.59 & 1.10 \\
\hline s14 Machinery- & 2.65 & -1.35 & 9.85 & 6.50 \\
\hline s15 Other Manufactured products & 0.62 & 0.72 & 5.81 & 4.29 \\
\hline a3 Services & -2.72 & -1.70 & 5.62 & 2.92 \\
\hline s16 Trade & -1.78 & -1.07 & 5.96 & 2.90 \\
\hline s17 Sea Transport & 1.56 & -0.37 & 0.53 & 0.16 \\
\hline s18 Air Transport & -0.45 & -0.38 & 1.43 & 0.38 \\
\hline s19 Other Transport & -1.22 & -0.66 & 1.98 & 0.68 \\
\hline s20 Communication & -2.55 & -1.58 & 4.75 & 1.89 \\
\hline s21 Finance & -2.93 & -1.831 & 3.96 & 7.11 \\
\hline s22 Insurance & -3.88 & -2.51 & 20.22 & 9.86 \\
\hline s23 Business services & -3.43 & -2.13 & 7.78 & $4 . .18$ \\
\hline s24 Recreation \& related Services & -0.89 & -0.46 & 1.52 & 0.87 \\
\hline s25 Admin Defence Health Education & -4.18 & -2.69 & 5.87 & 2.73 \\
\hline s26 Other Services & -1.76 & -0.96 & 10.50 & 4.38 \\
\hline TOTAL & 5.50 & 4.01 & 5.87 & 4.25 \\
\hline
\end{tabular}

for dairy products and meat as well as metals, machinery, electronic equipment, other manufactured products and transport services to a lesser extent.

Looking at overall trade effects in the EU (Table 10), a significant increase is recorded for especially cars and trucks (more than a 5\% rise in exports and more than a 7\% rise in imports). This expected result is due to the high level of NTBs in the Korean car industry. Similarly, a significant increase in meat and dairy product exports (more than 10\%) is also due to the liberalization of the Korean market in 
Table 12. Bilateral trade effects (\% change, sectoral breakdown)

\begin{tabular}{|c|c|c|c|c|}
\hline & \multicolumn{2}{|c|}{ EXPORTS: EU } & \multicolumn{2}{|c|}{ EXPORTS: KOREA } \\
\hline & Baseline 1 & Baseline 2 & Baseline 1 & Baseline 2 \\
\hline$\alpha 1$ Agriculture & 163.49 & 129.22 & 76.23 & 51.22 \\
\hline$\alpha 2$ NAMA & 83.97 & 64.90 & 37.51 & 21.82 \\
\hline$\alpha 3$ Services & 24.82 & 10.10 & -2.45 & -1.43 \\
\hline s01 Meat \& Animal products & 331.56 & 267.98 & 185.43 & 97.57 \\
\hline s02 Dairy & 1114.24 & 928.06 & 4221.63 & 611.64 \\
\hline s03 Other Agriculture & 259.96 & 215.87 & 82.98 & 50.98 \\
\hline s04 Food & 170.93 & 146.12 & 80.91 & 40.87 \\
\hline s05 Beverage \& Tobacco & 68.19 & 65.48 & 47.98 & 34.28 \\
\hline s06 Primary & 84.76 & 82.65 & 60.84 & 60.11 \\
\hline s07 Textile & 175.01 & 111.36 & 182.95 & 96.07 \\
\hline s08 Leather \& Clothing & 148.96 & 77.60 & 210.70 & 93.73 \\
\hline s09 Chemicals & 89.70 & 61.22 & 65.54 & 50.22 \\
\hline s10 Metals & 77.64 & 60.75 & 9.52 & 6.62 \\
\hline s11 Cars \& Trucks & 481.01 & 447.40 & 131.57 & 50.38 \\
\hline s12 Planes Ships Bikes Trains & 55.62 & 46.35 & 18.32 & 21.91 \\
\hline s13 Electronic equipment & 65.77 & 59.65 & 6.76 & 3.40 \\
\hline s14 Machinery & 84.71 & 59.78 & 9.09 & 7.46 \\
\hline s15 Other Manufactured products & 50.62 & 42.37 & 31.65 & 26.78 \\
\hline s16 Trade & 44.93 & 18.90 & -1.58 & -0.81 \\
\hline s17 Sea Transport1 & 0.74 & -0.58 & 1.82 & -0.24 \\
\hline s18 Air Transport & 10.06 & -0.28 & -0.31 & -0.23 \\
\hline s19 Other Transport & 14.67 & -0.26 & -0.98 & -0.40 \\
\hline s20 Communication & 35.54 & 5.09 & -2.41 & -1.38 \\
\hline s21 Finance & 62.49 & 31.96 & -2.80 & -1.66 \\
\hline s22 Insurance & 79.14 & 39.87 & -3.67 & -2.26 \\
\hline s23 Business services & 31.90 & 16.62 & -3.28 & -1.93 \\
\hline s24 Recreation \& related Services & 1.32 & 0.62 & -0.63 & -0.16 \\
\hline s25 Admin Defence Health Education & 42.19 & 0.54 & -3.96 & -2.39 \\
\hline s26 Other Services & 99.78 & 39.26 & -1.56 & -0.72 \\
\hline TOTAL & 82.58 & 62.8 & 38.39 & 23.06 \\
\hline
\end{tabular}

the FTA. Metal, electronic equipment, machinery as well as leather/clothing also exhibit a significant export increase because of Korean NTB cuts. However, exports are expected to be reduced in textiles.

On the import side, the main import growth concern cars and trucks, textiles as well as other transport equipment to a lesser extent. Finally, for both imports and exports, changes are very small for EU trade in services.

With regard to Korean trade (Table 11), significant increases are found for 
leather/clothing (exports), textiles (mainly exports), cars, other transport equipment and chemicals (exports and imports), meat, food and dairy products (mainly imports), machinery, metals, other manufactured products as well as most services, especially finance, insurance and business services (imports).

With regard to textiles, it must be observed that the expansion of Korean exports to the EU will however be limited by the fact that the rules of origins negotiated in the agreement are more stringent than those currently applied. Since this is not taken into account in the CGE model, the figures concerning textiles may be overestimated. The Korean exports performance in the car sector is also likely to be overestimated. The study is based on a dataset benchmarked to the year 2004 and does therefore not take into account the most recent creation of new Korean car production capacity in the EU and in third countries. This trend, which is likely to continue also in the coming years, implies an increase of shipment of Koreanbranded cars from other countries than Korea.

Table 12 on the bilateral trade effects makes it possible to go further in the analysis and draw some conclusions. First, the most important export increase from the EU to Korea concerns cars and truck (about 400\%). As expected, this means that the EU-Korea FTA will provide significant gains for EU car exporters in terms of market access into Korea. ${ }^{19}$

It must also be observed that Korea will also increase its car exports to the EU, though to a lesser extent (131\%). However, if Korea implements an FTA with the USA and Canada (baseline 2), the increase in Korean car exports to the EU will be smaller $(50.4 \%) .{ }^{20}$ In this regard, intra-industry trade will strongly increase in the car industry with significant gains in terms of product variety and efficiency. Finally, it must be noted that the rise in EU car imports from Korea is partly balanced by the reduction in imports from third countries.

A second result shows that the EU is also in a position to significantly increase its exports of other industrial products (up to $84 \%$ ) as a result of Korean reduction in NTBs. In particular, machinery and electronic equipment exports which currently account for one-third of EU overall exports to Korea, are expected to grow by more than $65 \%$ in the most favorable scenario. Again, if the EU and

\footnotetext{
${ }^{19}$ However, this sector shows significant trade diversion, since EU exports to the other countries (especially, Chile, Asian countries and intra-EU) are reduced by up to $4.9 \%$ (Table 13). Consequently, the overall rise in EU exports of cars is still significant, but limited to $5.5 \%$ (i.e. 7.6 billion euros).

${ }^{20} \mathrm{In}$ any case, the increase in Korean exports of cars to the EU as well as trade diversion explain that overall production effects in the car industry in the EU are slightly negative $(-1.38 \%$ in baseline 1 and $-0.40 \%$ in baseline 2 ).
} 
Table 13. Bilateral trade effects : the car industry (\% change, Exporter: EU)

\begin{tabular}{lcccc}
\hline EXPORTS of cars: EU & \multicolumn{3}{c}{ Baseline 2} \\
\hline & Baseline 1 & & \\
\cline { 2 - 5 } & $\%$ & billion euros & $\%$ & billion euros \\
\cline { 2 - 5 } r02 Korea & $\mathbf{4 8 1 . 0 1}$ & $\mathbf{8 . 1 9}$ & $\mathbf{4 4 7 . 4 0}$ & $\mathbf{7 . 9 6}$ \\
r03 Japan & -1.03 & -0.07 & -0.58 & -0.04 \\
r04 USA & -1.52 & -0.54 & -0.86 & -0.33 \\
r05 China \& Taiwan & -2.33 & -0.10 & -1.38 & -0.08 \\
r06 ASEAN & -3.16 & -0.06 & -1.78 & -0.03 \\
r07 India & -4.92 & -0.01 & -1.11 & -0.02 \\
r08 Oceania & -1.26 & -0.05 & -0.60 & -0.03 \\
r09 Canada & -1.49 & -0.04 & -0.92 & -0.03 \\
r10 EFTA & -0.88 & -0.10 & -0.48 & -0.05 \\
r11 Brazil & -0.62 & -0.01 & -0.24 & -0.01 \\
r12 Chile & -4.72 & -0.02 & -2.73 & -0.01 \\
r13 Russia & -2.03 & -0.11 & -1.11 & -0.06 \\
r14 Rest of World & -1.84 & -0.71 & -1.04 & -0.40 \\
\hline
\end{tabular}

Korea implement FTAs with other countries (ambitious baseline), this bilateral increase will be smaller. As a result of this export increase, intra-industry trade may also develop, since EU producers will enjoy a better market access in Korea, especially in consumer electronics. It must also be observed that the EU is expected to increase its exports of textiles and leather-clothing to Korea. This would increase intra-industry trade for these products (vertical product differentiation). However, as for the car industry, there is significant trade diversion for EU exports, which decrease with the other partners. This explains why the EU production in this industry slightly declines.

Third, the EU is expected to significantly increase its exports of agricultural products, especially meat and dairy products. Although Korean export increases are also high in the simulation for these products, it must be reminded that Korean exports are close to zero in the baseline (this mainly explains these extremely high figures).

Results concerning chemicals, other transport equipment, other manufactured products (and textiles/leather/clothing) exhibit a significant rise in bilateral exports for both the EU and Korea. This can lead to increasing competition and intraindustry trade for these sectors.

Finally, trade in services shows important differences between the EU and Korea. EU exports to Korea are expected to increase by more than $30 \%$ for almost 
Table 14. Bilateral trade effects (billion euros, sectoral breakdown)

\begin{tabular}{|c|c|c|c|c|c|c|}
\hline & \multicolumn{2}{|c|}{$\begin{array}{l}\text { EU exports to } \\
\text { Korea }\end{array}$} & \multicolumn{2}{|c|}{$\begin{array}{l}\text { EU imports } \\
\text { from Korea }\end{array}$} & \multicolumn{2}{|c|}{$\begin{array}{l}\text { Bilateral EU } \\
\text { trade balance }\end{array}$} \\
\hline & Baseline 1 & Baseline 2 & Baseline 1 & Baseline 2 & Baseline 1 & Baseline 2 \\
\hline Q1 Agriculture & 8.48 & 6.82 & 4.74 & 3.87 & 3.74 & 2.95 \\
\hline$\alpha 2$ NAMA & 30.71 & 25.36 & 29.75 & 19.12 & 0.96 & 6.24 \\
\hline$\alpha 3$ Services & 1.89 & 0.84 & -0.09 & -0.05 & 1.97 & 0.89 \\
\hline s01 Meat \& Animal products & 2.02 & 1.32 & 0.00 & 0.00 & 2.02 & 1.32 \\
\hline s02 Dairy & 1.63 & 1.39 & 0.01 & 0.01 & 1.62 & 1.38 \\
\hline s03 Other Agriculture & 0.58 & 0.53 & 0.02 & 0.01 & 0.57 & 0.52 \\
\hline s04 Food & 1.16 & 1.02 & 0.09 & 0.06 & 1.08 & 0.96 \\
\hline s05 Beverage \& Tobacco & 0.32 & 0.31 & 0.00 & 0.00 & 0.32 & 0.31 \\
\hline s06 Primary & 0.39 & 0.30 & 0.01 & 0.01 & 0.38 & 0.29 \\
\hline s07 Textile & 0.64 & 0.48 & 4.25 & 3.54 & -3.61 & -3.05 \\
\hline s08 Leather \& Clothing & 1.43 & 0.87 & 1.21 & 0.84 & 0.23 & 0.03 \\
\hline s09 Chemicals & 6.38 & 4.72 & 1.27 & 1.08 & 5.11 & 3.64 \\
\hline s10 Metals & 1.72 & 1.47 & 0.36 & 0.24 & 1.37 & 1.23 \\
\hline s11 Cars \& Trucks & 8.53 & 8.292 & 1.931 & 3.27 & -13.39 & -4.98 \\
\hline s12 Planes Ships Bikes Trains & 0.45 & 0.40 & 1.38 & 1.43 & -0.93 & -1.04 \\
\hline s13 Electronic equipment & 1.61 & 1.54 & 2.21 & 1.11 & -0.61 & 0.43 \\
\hline s14 Machinery & 5.88 & 4.76 & 1.67 & 1.31 & 4.21 & 3.45 \\
\hline $\begin{array}{l}\text { s15 Other Manufactured } \\
\text { products }\end{array}$ & 5.47 & 4.60 & 0.09 & 0.08 & 5.38 & 4.52 \\
\hline s16 Trade & 0.38 & 0.19 & -0.01 & -0.00 & 0.39 & 0.19 \\
\hline s17 Sea Transport & 0.41 & -0.02 & 0.01 & -0.00 & 0.41 & -0.02 \\
\hline s18 Air Transport & 0.28 & -0.01 & -0.00 & -0.00 & 0.29 & -0.01 \\
\hline s19 Other Transport & 0.15 & -0.00 & -0.00 & -0.00 & 0.15 & -0.00 \\
\hline s20 Communication & 0.04 & 0.01 & -0.01 & -0.00 & 0.04 & 0.01 \\
\hline s21 Finance & 0.10 & 0.06 & -0.02 & -0.01 & 0.12 & 0.07 \\
\hline s22 Insurance & 0.28 & 0.17 & -0.00 & -0.00 & 0.28 & 0.17 \\
\hline s23 Business services & 1.05 & 0.61 & -0.05 & -0.03 & 1.10 & 0.64 \\
\hline $\begin{array}{l}\text { s24 Recreation \& related } \\
\text { Services }\end{array}$ & 0.01 & 0.00 & -0.00 & -0.00 & 0.01 & 0.00 \\
\hline $\begin{array}{l}\text { s25 Admin Defence Health } \\
\text { Education }\end{array}$ & 0.14 & 0.00 & -0.00 & -0.00 & 0.14 & 0.00 \\
\hline s26 Other Services & 0.02 & 0.01 & -0.00 & -0.00 & 0.02 & 0.01 \\
\hline TOTAL & 41.08 & 33.02 & 34.41 & 22.9 & 56.68 & 10.08 \\
\hline
\end{tabular}

all services, especially finance, insurance, communication as well as business and other services. On the other hand, a decrease in Korean service exports to the EU is expected, with the exception of sea transport. This result reflects the comparative advantage of EU services with regard to Korea. 
Additional results may be provided by analyzing bilateral trade effects in value (including trade balances). In this regard, EU exports to Korea significantly exceed imports for chemicals, machinery and other manufactured products (Table 14). This leads to an improvement of the EU bilateral trade balance by about 15 billion euros for these industries taken together. The other sectors with positive effects on the EU bilateral trade balance include agriculture and food products (meat, dairy and other food product for about 5 billion euros) as well as services (up to 2 billion euros).

On the other hand, the rise in EU bilateral imports of cars exceeds that of exports. Consequently, the EU trade balance regarding the car industry deteriorates by 5 billion euros or 13 billion euros depending on the baseline considered. Other EU trade balance deterioration concerns textiles ( 3 billion euros).

Overall, as already shown, the EU bilateral trade balance with Korea is expected to improve by about 6.7 billion euros in baseline 1 and 10.1 billion euros in baseline 2 . This would contribute to reducing the current bilateral trade deficit that the EU faces vis-á-vis Korea (13.8 billion euros in 2008).

Table 15 shows that the effects on EU employment are very small. ${ }^{21}$ The only effects which are greater than $1.5 \%$ concern textiles (down to $-2.3 \%$ ). With regard to textiles, employment effects may be overestimated since MIRAGE does not take into account the effects of the stricter rules of origin negotiated in the agreement. Moreover, this industry accounts for less than $0.5 \%$ of the skilled and unskilled labour force in the EU. In addition, the negative effects in the shrinking industries (especially textiles) are balanced by positive employment effects in expanding sectors (machinery, chemicals, other manufactured products and transport services). This leaves overall employment unchanged. It must also be stressed that employment effects in the car industry are small but slightly negative whatever the baseline.

Employment effects for Korea are a bit more significant (Table 16). In particular, employment in textile and leather/clothing increases significantly. However, these industries amount to a very small part of total employment in Korea. Significant positive effects are also recorded for cars (and other transport equipment to a lesser extent). The most significant decrease in Korean employment is recorded for dairy products and meat (whose share of total employment is very small). Smaller

\footnotetext{
${ }^{21}$ Employment effects are presented in \% change, as MIRAGE does not directly include employment figures. In addition, these effects are not strictly comparable across sectors. This explains that Table 15 does not provide summarized effects across sectors.
} 
Table 15. Effects on sectoral employment: European Union ( \%)

\begin{tabular}{|c|c|c|c|c|c|c|}
\hline & \multicolumn{3}{|c|}{ EU skilled } & \multicolumn{3}{|c|}{ EU unskilled } \\
\hline & Baseline & Baseline & share in & Baseline & Baseline & share in \\
\hline & 1 & 2 & total empl. & 1 & 2 & total empl. \\
\hline s01 Meat \& Animal products & 0.93 & 0.56 & $0.2 \%$ & 0.99 & 0.60 & $0.7 \%$ \\
\hline s02 Dairy & 0.66 & 0.52 & $0.3 \%$ & 0.74 & 0.58 & $0.9 \%$ \\
\hline s03 Other Agriculture & 0.11 & 0.07 & $0.3 \%$ & 0.12 & 0.07 & $2.8 \%$ \\
\hline s04 Food & 0.16 & 0.13 & $0.8 \%$ & 0.17 & 0.13 & $1.8 \%$ \\
\hline s05 Beverage \& Tobacco & 0.13 & 0.12 & $0.1 \%$ & 0.14 & 0.12 & $0.3 \%$ \\
\hline s06 Primary & -0.02 & -0.03 & $0.3 \%$ & -0.02 & -0.04 & $0.4 \%$ \\
\hline s07 Textile & -2.25 & -2.10 & $0.2 \%$ & -2.30 & -2.17 & $0.5 \%$ \\
\hline s08 Leather \& Clothing & 0.02 & -0.11 & $0.2 \%$ & 0.06 & -0.09 & $0.7 \%$ \\
\hline s09 Chemicals & 0.19 & 0.09 & $2.6 \%$ & 0.20 & 0.09 & $3.2 \%$ \\
\hline s10 Metals & 0.04 & 0.09 & $1.5 \%$ & 0.03 & 0.08 & $3.1 \%$ \\
\hline s11 Cars \& Trucks & -1.42 & -0.42 & $1.3 \%$ & -1.50 & -0.47 & $2.4 \%$ \\
\hline s12 Planes Ships Bikes Trains & -0.38 & -0.65 & $0.4 \%$ & -0.38 & -0.66 & $0.7 \%$ \\
\hline s13 Electronic equipment & 0.06 & 0.04 & $0.7 \%$ & 0.07 & 0.05 & $0.9 \%$ \\
\hline s14 Machinery & 0.30 & 0.20 & $3.6 \%$ & 0.30 & 0.19 & $4.4 \%$ \\
\hline s15 Other Manufactured products & 0.18 & 0.13 & $2.7 \%$ & 0.18 & 0.13 & $5.4 \%$ \\
\hline s16 Trade & -0.00 & -0.00 & $8.3 \%$ & -0.01 & -0.01 & $15.8 \%$ \\
\hline s17 Sea Transport & 0.33 & 0.07 & $0.3 \%$ & 0.32 & 0.05 & $0.6 \%$ \\
\hline s18 Air Transport & 0.12 & -0.05 & $0.2 \%$ & 0.12 & -0.07 & $0.5 \%$ \\
\hline s19 Other Transport & 0.08 & 0.03 & $2.6 \%$ & 0.07 & 0.02 & $5.0 \%$ \\
\hline s20 Communication & -0.00 & -0.02 & $2.5 \%$ & -0.01 & -0.03 & $1.6 \%$ \\
\hline s21 Finance & -0.01 & -0.02 & $4.1 \%$ & -0.01 & -0.03 & $2.7 \%$ \\
\hline s22 Insurance & 0.03 & -0.01 & $1.7 \%$ & 0.02 & -0.01 & $1.1 \%$ \\
\hline s23 Business services & 0.00 & -0.01 & $15.4 \%$ & -0.00 & -0.02 & $9.0 \%$ \\
\hline $\begin{array}{l}\text { s24 Recreation \& related } \\
\text { Services }\end{array}$ & -0.03 & -0.02 & $4.5 \%$ & -0.03 & -0.03 & $2.8 \%$ \\
\hline $\begin{array}{l}\text { s25 Admin Defence Health } \\
\text { Education }\end{array}$ & -0.01 & -0.01 & $40.1 \%$ & -0.01 & -0.01 & $24.7 \%$ \\
\hline s26 Other Services & 0.01 & 0.01 & $5.0 \%$ & 0.00 & -0.00 & $8.2 \%$ \\
\hline
\end{tabular}

decreases are found in some manufactured products as well as some services (business services, transport services and insurance). However, overall employment effects are very small. As a result, the EU-Korea FTA is unlikely to produce significant disruption of labour markets, both in the EU and in Korea. This conclusion correlates with that corresponding to the Trade SIA study (IBM, 2008), which shows that employment effects are insignificant for the EU whatever the industry considered. Effects on Korean employment are slightly higher but 
Table 16. Effects on sectoral employment: Korea (\%)

\begin{tabular}{|c|c|c|c|c|c|c|}
\hline & \multicolumn{3}{|c|}{ Korea skilled } & \multicolumn{3}{|c|}{ Korea unskilled } \\
\hline & Baseline & Baseline & share in & Baseline & Baseline & share in \\
\hline & 1 & 2 & total empl. & 1 & 2 & $\overline{\text { total empl. }}$ \\
\hline s01 Meat \& Animal products & -9.41 & -4.70 & $0.1 \%$ & -10.19 & -5.24 & $0.2 \%$ \\
\hline s02 Dairy & -22.74 & -18.23 & $0.1 \%$ & -24.80 & $-20 . .06$ & $0.2 \%$ \\
\hline s03 Other Agriculture & -1.26 & -0.86 & $0.1 \%$ & -1.93 & -1.33 & $2.2 \%$ \\
\hline s04 Food & -3.05 & -2.33 & $0.4 \%$ & -3.53 & -2.68 & $0.4 \%$ \\
\hline s05 Beverage \& Tobacco & -0.84 & -0.85 & $0.1 \%$ & -1.35 & -1.22 & $0.2 \%$ \\
\hline s06 Primary & -0.80 & -0.54 & $0.1 \%$ & -1.38 & -0.94 & $0.2 \%$ \\
\hline s07 Textile & 34.85 & 24.35 & $0.3 \%$ & 35.13 & 24.26 & $0.7 \%$ \\
\hline s08 Leather \& Clothing & 11.52 & 9.99 & $0.2 \%$ & 10.87 & 9.61 & $0.4 \%$ \\
\hline s09 Chemicals & -0.79 & -0.57 & $1.4 \%$ & -1.19 & -0.87 & $1.4 \%$ \\
\hline s10 Metals & -2.43 & -1.99 & $2.9 \%$ & -2.86 & -2.29 & $4.2 \%$ \\
\hline s11 Cars \& Trucks & 22.40 & 9.80 & $2.4 \%$ & 22.42 & 9.76 & $3.3 \%$ \\
\hline $\begin{array}{l}\text { s12 Planes Ships Bikes } \\
\text { Trains }\end{array}$ & 0.87 & 3.99 & $1.0 \%$ & 0.38 & 3.64 & $1.4 \%$ \\
\hline s13 Electronic equipment & -2.01 & -1.08 & $3.2 \%$ & -2.58 & -1.50 & $3.4 \%$ \\
\hline s14 Machinery & -3.33 & -2.19 & $7.7 \%$ & -3.74 & -2.48 & $8.7 \%$ \\
\hline $\begin{array}{l}\text { s15 Other Manufactured } \\
\text { products }\end{array}$ & -1.61 & -1.40 & $1.2 \%$ & -2.06 & -1.73 & $1.6 \%$ \\
\hline s16 Trade & 0.15 & 0.10 & $6.3 \%$ & -0.26 & -0.20 & $10.1 \%$ \\
\hline s17 Sea Transport & -0.06 & -0.19 & $0.1 \%$ & -0.52 & -0.52 & $0.2 \%$ \\
\hline s18 Air Transport & -1.12 & -0.24 & $0.2 \%$ & -1.56 & -0.56 & $0.3 \%$ \\
\hline s19 Other Transport & -0.22 & -0.03 & $2.4 \%$ & -0.59 & -0.30 & $4.0 \%$ \\
\hline s20 Communication & -0.56 & -0.36 & $2.5 \%$ & -1.02 & -0.69 & $1.8 \%$ \\
\hline s21 Finance & -0.50 & -0.35 & $4.4 \%$ & -0.91 & -0.65 & $3.4 \%$ \\
\hline s22 Insurance & -0.97 & -0.62 & $2.8 \%$ & -1.15 & -0.76 & $2.6 \%$ \\
\hline s23 Business services & -1.31 & -0.83 & $9.9 \%$ & -1.68 & -1.10 & $7.9 \%$ \\
\hline $\begin{array}{l}\text { s24 Recreation \& related } \\
\text { Services }\end{array}$ & 0.27 & 0.19 & $3.4 \%$ & 0.02 & 0.01 & $3.0 \%$ \\
\hline $\begin{array}{l}\text { s25 Admin Defence Health } \\
\text { Education }\end{array}$ & -0.17 & -0.11 & $40.4 \%-$ & 0.23 & -0.17 & $25.5 \%$ \\
\hline s26 Other Services & 0.51 & 0.36 & $6.4 \%$ & 0.01 & -0.00 & $0.0 \%$ \\
\hline
\end{tabular}

generally below $1 \%$ for each industry, except textiles, cars and trucks as well as other transport equipment.

As compared with the Copenhagen study, the basic macroeconomic results are similar in terms of GDP changes. However, the bilateral trade growth is slightly higher in the present study. These differences can be mainly explained by the inclusion of NTB cuts in the present study which lead to additional trade effects 
but few GDP effects. The other explanations of the differences across the two studies are related to differences in the baseline and scenarios (which are closer to the official agreement in the present study). Another reason is due to differences in the calculation of protection in services. The Copenhagen study provides an overall protection rate which applies to all services, whereas the present study calculates protection for each service category.

Sectoral results are more different, as expected. In particular, the Copenhagen study expects a decrease in the EU production of manufactured goods (and a corresponding rise in Korea). In the present study, this is generally not expected given that the $\mathrm{EU}$ is in a position to take advantage of the significant reduction in the high initial NTBs in Korea. In particular, the production of chemicals, machinery and other manufactured products is generally expected to increase and the $\mathrm{EU}$ is in a position to increase the exports of these products.

Finally, as compared to the Kim (2005) and Ko (2006) studies, conceptual differences are more significant than with the Copenhagen study for several reasons. First, these two studies do not include imperfect competition. Second, the derivation of NTBs in services uses a different method. Third, the baselines are also very different (the Pukyong study concentrates more on manufactured products than on services, the tariff schedules are different, Doha is disregarded as well as the other FTAs under negotiation with Korea). Given these significant differences, the results of those studies are hardly comparable to those found in the present study.

Interestingly, our results can also be compared with those of Baughman and Francois (2009), which quantify the cost for the USA of the failure to implement the US-Korea FTA, assuming that the EU-Korea FTA and the Canada-Korea FTA are implemented. Results show that the USA would lose 35.1 billion dollars in terms of exports, 40.1 billion dollars in terms of GDP as well as 345,000 jobs.

\section{Sensitivity Analysis}

The robustness of the results has been checked with regard to (1) the values of the elasticities of substitution; (2) the values of NTBs; (3) the consideration of trade facilitation and (4) the magnitude of the reduction in protection for services.

More precisely, the first sensitivity analysis (S1) includes a reduction of the elasticities of substitution by $50 \%$; the second set (S2) uses $50 \%$ higher values of NTBs. The third sensitivity analysis (S3) includes trade facilitation. This is taken into account by considering that the time which is necessary to accomplish import 
procedures, such as customs procedure and time for processing goods at the port (Decreux and Fontagné, 2009). Finally, the last set of results (S4) considers a greater reduction $(30 \%$ instead of $10 \%)$ in the protection of specific services, namely telecom, financial and business services. In order to save space, the detailed results of the sensitivity analyses are not presented here but are available upon request from the authors.

$\mathrm{S} 1$ generally reduces and smoothes all the effects (production, trade, employment, terms of trade, etc) but leaves the basic conclusions unchanged. Conversely, S2 leads to amplified effects compared with the central simulation. This is due to the fact that S2 includes higher NTB values than in the central simulation. In this case, the FTA would lead to an increase in EU exports, imports and trade balance by about 74, 46 and 28 billion euros respectively. Again, the basic conclusions are generally unchanged.

S3, which considers trade facilitation, provides small additional gains for both the EU and Korea, especially with regard to trade, production and employment. The last sensitivity analysis (S4) provides insignificant changes in comparison with the central simulation, except for the specific services considered. In particular, bilateral EU exports to Korea are significantly increased for finance, communication, business services as well as insurance. Other macroeconomic effects are not significantly changed whatever the sensitivity analysis considered.

\section{Conclusion}

This study provides new insights into the quantitative assessment of the effects of the EU-Korea FTA. The originality and contributions of this research are related to:

- The adoption of simulations which are very close to the official agreement, especially concerning tariff cuts in goods and reduction in protection for services.

- The incorporation of NTBs liberalisation.

- The use of a new version of the MIRAGE CGE model, which includes key characteristics in imperfect competition (vertical product differentiation, the specific modeling of trade costs and their components, the inclusion of FDI as well as the consideration of dynamics).

The overall results show that the effects of the EU-Korea FTA on GDP are positive for both the EU $(0.08 \%)$ and Korea (up to $0.84 \%$ ). Welfare gains are also 
positive and significant, especially for Korea (up to $1.12 \%$ ).

With regard to trade, both the EU and Korea show a positive effect on exports and imports. The EU bilateral trade with Korea increases very significantly (up to $82.6 \%$ ), as a result of the initial high protection in Korea. Consequently, the EU bilateral trade balance with Korea is expected to improve by up to 10.1 billion euros. However, there is evidence of partial trade diversion for the EU, which replaces parts of its exports to the rest of the world by exports to Korea.

Sectoral results show that the EU may improve its position (especially with regard to its trade balance) in several industries (chemicals, machinery, other manufactured products and specific agricultural/food products) as well as in specific services to a lesser extent (business, insurance and transport services). On the other hand, Korea takes advantage of the agreement by improving its trade position for specific manufactured products (textile, leather/clothing, cars and other transport equipment).

The analysis of the car industry provides interesting results with a sharp increase in both Korean and EU exports (intra-industry trade). The rise in intra-industry trade is also expected for some other industries (textiles, chemicals other transport equipment as well as other manufactured products).

Effects on production and employment are small, especially for the EU. At sectoral level, employment effects for Korea are more significant, with a positive impact for textiles, leather/clothing as well as for cars. Conversely, negative effects are expected for specific manufactured products (machinery, electronic equipment and other manufactured products), specific services (business, transport and insurance) as well as dairy products and meat.

\section{Acknowledgement}

This article has been written with financial assistance from the Commission of the European Communities (DG Trade, framework contract TRADE/07/A2: Korea II with CEPII/ATLASS consortium). The views expressed herein are those of the authors and therefore in no way reflect the official opinion of the European Commission. The authors are grateful to Lionel Fontagné (CEPII and Paris school of Economics) for useful comments and suggestions. Thanks also to Thomas Chappuis for research assistance concerning MIRAGE, Danny McGowan and Tobias Ketterer (GEP, Nottingham) for invaluable research support. 
Received 30 July 2010, Revised 7 September 2010, Accepted 15 September 2010

\section{References}

Anderson J. and E. van Wincoop (2004), Trade Costs, Journal of Economic Literature, 42(3), pp. 691-751.

Baughman, L. And J. Francois (2009), Failure to Implement the US-Korea Free Trade Agreement: The Cost for American Workers and Compagnies, US-Korea Business Council, http://www.uschamber.com/NR/rdonlyres/ejyp7lxtnmxyjbsbmymhens 5oi35ay2 wnr77sevx6tt4q3sfrsk7dijx6excatatit22erv6c6xo63drezuvonjskog/ 0911_fta_korea.pdf.

Blot, C. and M. Cochar (2008), L'énigme des exportations revisitée: Que faut-il retenir des données de panel?, Revue de L'OFCE, 106, pp. 67-100.

CEPS (2007), A Qualitative Analysis of a Potential Free Trade Area between the European Union and South Korea, Centre for European Policy Studies and Korean Institute for International and Economic Policy, Report for the European Commission, DG Trade.

Copenhagen Economics, (2007), A Quantitative Analysis of a Potential Free Trade Agreement between the EU and South Korea, study prepared for the European Commission, DG Trade, Brussels.

Decreux, Y. and L. Fontagné (2009), Economic Impact of Potential Outcome of the DDA, Rapport d'Etude CEPII No. 29-01.

Decreux, Y. and H. Valin (2007), MIRAGE, Updated Version of the Model for Trade Policy Analysis: Focus on Agriculture and Dynamics, CEPII Working Paper 2007/15.

European Commission (2009a), EU-Korea FTA online, DG Trade, 20 October 2009, http://trade.ec.europa.eu/doclib/press/index.cfm?id=443\&serie=273\&langId=en.

European Commission (2009b), EU-Korea FTA: a quick reading guide, DG trade, 20 October 2009, http://trade.ec.europa.eu/doclib/docs/2009/october/tradoc_145203.pdf.

European Commission (2010), The Economic Significance of Duty Drawbacks in the Context of the EU-Korea FTA, DG Trade, mimeo.

Findlay, C. and T. Warren (2000), Impediments to Trade in Services: Measurement and Policy Implications, Routledge, London and New York.

Fontagné, L., T. Mayer and S. Zignago (2005), Trade in the Triad : How easy is the Access to Large Markets?, Canadian Journal of Economics, 38(4).

Fontagné, L., A. Guillin and C. Mitaritonna (2009), Estimations of Tariff Equivalents for the Service Sector, DG Trade Report, ATLASS.

Fontagné, L. and C. Mitaritonna (2009), Assessing Barriers to Trade in the Distribution and Telecom Sectors in Emerging Countries, CEPII Working Paper 2009-37.

IBM Belgium in association with DMI, TAC \& TICON, (2008), Trade Sustainability Impact Assessment of the Free Trade Agreement to be negotiated between the European Community and the Republic of Korea Final Report - (Phase 3), Framework Contract 
Commission 2007 Lot n 5 - project $\mathrm{N}^{\circ} 2007 / 139648$, http://trade.ec.europa.eu/doclib/ docs/2008/december/tradoc_141662.pdf.

Kee, H., A. Nicita and M.Olarreaga (2009), Estimating Trade Restrictiveness Indices, Economic Journal, 119(534), pp. 172-199.

Kee, H., A. Nicita and M.Olarreaga (2008), Import Demand Elasticities and Trade Distortions, Review of Economics and Statistics, 90(4), pp. 666-682.

Kim, H. (2005), An Analysis of the Economic Effects of the Korea-EU FTA, KIEP study, Korea Institute for International Economic Policy.

Ko, J.H. (2006), Analysis of Economic Effects of a Korea-EU FTA, powerpoint presentation at Conference on Korea's FTA Policy and Korea-EU FTA: Assessment and Prospective, organized by the European Union Studies Association of Korea and the Korean Society of Contemporary European Studies, Graduate School of International Studies of Seoul National University, 25 August 2005.

Park, S. (2002), Measuring Tariff Equivalents in Cross-Border Trade in Services, Trade working paper 353, East Asian Bureau of Economic Research.

Péridy, N. and N. Uttama (2010), Foreign Direct Investment and Productivity Spillovers: The Experience of ASEAN countries, Journal of Economic Integration, 25(2), pp. 298-323. WTO (2009), Trade Policy Review: Republic of Korea, WT/TPRs/S/204/Rev.1.

WTO (2010), Regional Trade Agreements Information System (RTA-IS), www.wto.org. 